\title{
A BioDesign Approach to Obtain High Yields of Biosimilars by Anti-apoptotic Cell Engineering: a Case Study to Increase the Production Yield of Anti-TNF Alpha Producing Recombinant CHO Cells
}

\author{
Sultan Gulce $\mathrm{Iz}^{1}$ (D) Muge Anil Inevi ${ }^{1,2}$. \\ Pelin Saglam Metiner ${ }^{1}$ - Duygu Ayyildiz Tamis ${ }^{1,3}$. \\ Nazli Kisbet ${ }^{1,4}$
}

Received: 25 April 2017 / Accepted: 14 June 2017 /

Published online: 6 July 2017

(C) Springer Science+Business Media, LLC 2017

\begin{abstract}
Recent developments in medical biotechnology have facilitated to enhance the production of monoclonal antibodies (mAbs) and recombinant proteins in mammalian cells. Human mAbs for clinical applications have focused on three areas, particularly cancer, immunological disorders, and infectious diseases. Tumor necrosis factor alpha (TNF- $\alpha$ ), which has both proinflammatory and immunoregulatory functions, is an important target in biopharmaceutical industry. In this study, a humanized anti-TNF- $\alpha$ mAb producing stable $\mathrm{CHO}$ cell line which produces a biosimilar of Humira (adalimumab) was used. Adalimumab is a fully human anti-TNF mAb among the top-selling $\mathrm{mAb}$ products in recent years as a biosimilar. Products from mammalian cell bioprocesses are a derivative of cell viability and metabolism, which is mainly disrupted by cell death in bioreactors. Thus, different strategies are used to increase the product yield. Suppression of apoptosis, also called anti-apoptotic cell engineering, is the most remarkable strategy to enhance lifetime of cells for a longer production period. In fact, using anti-apoptotic cell engineering as a BioDesign approach was inspired by nature; nature gives prolonged life span to some cells like stem cells, tumor cells, and memory B and T cells, and researchers have been using this strategy for different purposes. In this study, as a biomimicry approach, anti-apoptotic cell engineering was used to increase the anti-TNF- $\alpha$
\end{abstract}

Sultan Gulce Iz

sultan.gulce.iz@ege.edu.tr; sultangulce@gmail.com

1 Department of Bioengineering, Faculty of Engineering, Ege University, 35100 Izmir, Bornova, Turkey

2 Department of Biotechnology and Bioengineering, Izmir Institute of Technology, 35430 Izmir, Urla, Turkey

3 Turgut Ilaclari A.S, 34394 Istanbul, Besiktas, Turkey

4 GlaxoSmithKline, 34394 Istanbul, Besiktas, Turkey 
$\mathrm{mAb}$ production from the humanized anti-TNF- $\alpha$ mAb producing stable $\mathrm{CHO}$ cell line by Bcl$\mathrm{xL}$ anti-apoptotic protein. It was shown that transient transfection of $\mathrm{CHO}$ cells by the $\mathrm{Bcl}-\mathrm{xL}$ anti-apoptotic protein expressing plasmid prolonged the cell survival rate and protected cells from apoptosis. The transient expression of Bcl-xL using $\mathrm{CHO}$ cells enhanced the anti-TNF- $\alpha$ production. The production of anti-TNF- $\alpha$ in CHO cells was increased up to $215 \mathrm{mg} / \mathrm{L}$ with an increase of $160 \%$ after cells were transfected with Bcl-xL expressing plasmid with polyethylenimine (PEI) reagent at the ratio of 1:6 (DNA:PEI). In conclusion, the antiapoptotic efficacy of the Bcl-xL expressing plasmid in humanized anti-TNF- $\alpha$ MAb producing stable $\mathrm{CHO}$ cells is compatible with curative effect for high efficiency recombinant protein production. Thus, this model can be used for large-scale production of biosimilars through transient Bcl-xL gene expression as a cost-effective method.

Keywords Anti-apoptotic cell engineering $\cdot \mathrm{Bcl}-\mathrm{xL} \cdot \mathrm{Chinese}$ hamster ovary cells · Polyethylenimine (PEI) - Transient gene expression (TGE)

\section{Introduction}

Monoclonal antibodies (mAbs) have recently gained considerable importance both for diagnostic and therapeutic applications in biopharmaceutical industry [1-4]. When therapeutic mAbs have succeeded in the treatment of immune diseases after entering clinical trials, the production of mAbs has become the fastest moving industry [5]. The progress in researches of $\mathrm{mAb}$ production is crucial from the point of lowering their production costs [6]. Tumor necrosis factor alpha (TNF- $\alpha$ ), which has both proinflammatory and immunoregulatory functions, is an important target in biopharmaceutical industry [7-9]. Commercial TNF antagonists comprise of engineered monoclonal antibodies and fusion proteins that have been successfully used for the treatment of the chronic inflammatory diseases such as RA, Crohn's disease, and psoriasis $[10,11]$. There are currently five TNF- $\alpha$ antibodies approved by the US Food and Drug Administration (FDA) for clinical applications on the market either chimeric, humanized, or fully human (i.e., etanercept, infliximab, adalimumab, certolizumab, and golimumab) $[12,13]$. Willrich et al. reported that FDA-approved TNF antagonists represent approximately $\$ 20$ billion in sales, and Humira (adalimumab), that is a top-selling drug of any class in 2012, achieved solely an annual sale of 9.3 billion US dollars [14, 15]. Anti-TNF- $\alpha$ agents are involved in important and promising group of drugs by virtue of prospects of implementation in several immune-mediated inflammatory diseases, and their market share and also biosimilars of anti-TNF- $\alpha$ agents are gaining importance. Thus, there is still a need to develop new strategies that provide cheaper production of mAbs with higher efficacy in the biopharmaceutical industry.

Mammalian cell lines are mostly the preferred expression systems for producing biopharmaceuticals due to their capability for production of complex proteins with posttranslational modifications (such as glycosylation) as is the case with proteins produced in humans $[16,17]$. Chinese hamster ovary (CHO) cells, human embryonic kidney 293 (HEK 293) cells, murine myeloma cells (NS0 and Sp2/0), and baby hamster kidney (BHK21) cells are the most prevalent non-human, mammalian cell lines used for recombinant protein production [18]. Recombinant $\mathrm{CHO}$ ( $\mathrm{rCHO}$ ) cells frequently used mammalian expression systems for large-scale production of biopharmaceuticals to satisfy the huge market demand due to their adaptation capability to suspension culture, high cell growth rate, high protein 
production yield, and resistance to mechanical stress [10-19], mostly when they are used for stable expression [20, 21].

Overall protein production in bioreactor cultures is a function of total viable cell number and production yield. However, cell death decreases the protein production; thus, prolongation of cells' survival results in enhanced production yield. Therefore, there is a commercial need to identify methods for prolongation of cells' lifetime [22, 23]. The cell death in bioreactor culture occurs due to mainly apoptosis when proteolytic caspases are activated in control of survival and death genes in consequence of the several conditions such as nutrient shortage and oxygen deficiency [24, 25], and sometimes autophagy also occurs [26]. The prolongation of cells' lifetime brings various benefits such as increasing production yields at diminished cost via increasing the time of production at one cycle, providing undiminished product quality, and simplifying downstream processes via preventing exposure of cells to debris and degradative enzymes [27]. The strategy of the delaying apoptosis via overexpression of anti-apoptotic genes has been used in several cells such as hybridoma [28, 29], CHO cells [27, 30], and NS0 myeloma cells [31]. The effectiveness of overexpressing anti-apoptotic genes, such as Bcl-2 or Bcl-xL, on maintaining cell viability is due to several unfavorable bioreactor production conditions such as limitation of various nutrients, exposure to toxin, shear stress, oxygen deprivation, and growth factor withdrawal [27, 32, 33]. Overexpressing anti-apoptotic genes in CHO cells compared to non-expressing cells increased the product titers [27, 34, 35]. Thus, anti-apoptotic cell engineering is a promising strategy to prolong the cell viability and to increase production yield of recombinant proteins via generating robust cell hosts [36].

Transient gene expression (TGE) is a technique to introduce foreign genetic material to cells without integration into the chromosome in contrast to the stable transfection; expression of the genetic material can be traced via a reporter gene usually within 1-2 days posttransfection [37, 38]. Many copies of a foreign gene are produced in the nucleus and the gene is transiently expressed to produce proteins in a faster and cheaper way [37-41]. Compared to stable transfection which requires almost 4-5 months to take the product, TGE requires a relatively short period, a maximum of 14 days, after transient transfection but low protein yield is a concern [37, 40]. For this reason, studies have been introduced to improve the foreign genetic material transfer to different cell lines by effective gene transfection reagents and electroporation techniques [37-41]. Polyethylenimine (PEI) which forms polyplexes with the plasmid DNA [40-44] and Lipofectamine ${ }^{\circledR}$ 2000, a cation-lipid formulation that produces liposomes in aqueous media, are the agents mostly used [38, 41], with a 40-90\% transfection efficiency [40-42]. Serum-free media is used to form uniform polyplexes and liposomes which make the toxicity of transfection reagents of particular concern in TGE systems [37-44]. Liposomal transfection reagents are reported to be more detrimental to cells than lipid or polyamine-based reagents $[41,45]$. Thus, PEI is selected to be used in transfection for high cell density culture for large-scale production due to its low toxicity and cost compared to cationic lipid agents [38-44].

In order to enhance production of anti-TNF- $\alpha \mathrm{mAb}$, anti-apoptotic cell engineering was evaluated as a BioDesign approach. The aim of the study is to evaluate the effect of transient expression of anti-apoptotic protein Bcl-xL on the production of anti-TNF- $\alpha$ $\mathrm{mAb}$. In line with this purpose, anti-TNF- $\alpha$ mAb producing stable $\mathrm{CHO}$ cell line was transiently transfected with the vector expressing anti-apoptotic Bcl-xL gene through both PEI and LPF. In the first part of the study, optimum transfection parameters were determined and in the second part, the effect of Bcl-xL overexpression on cell viability and production efficiency were evaluated. 


\section{Materials and Methods}

\section{Plasmid DNA}

The construction of Bcl-xL bearing pIRES2EGFP plasmid (Clontech, USA) was described previously [46]. The glyserol stocks of Escherichia coli DH5- $\alpha$ cells transformed with pIRES2EGFP/Bcl-xL plasmid were grown in Luria-Bertani (LB) medium (5 g of yeast extract, $2.5 \mathrm{~g}$ of tryptone, $2.5 \mathrm{~g} \mathrm{NaCl}$ ) containing $50 \mu \mathrm{g} / \mathrm{mL}$ kanamycine for 14-16 h. pIRES2EGFP/ Bcl-xL plasmid DNA was purified by using endotoxin-free plasmid maxi kit (Qiagen, 12362, USA) following users' instructions.

\section{Cell Culture and Maintenance}

Humanized anti-TNF- $\alpha$ mAb, suspension culture, and serum-free medium adapted stable $\mathrm{CHO}$ cell line were obtained from Creative Biolabs, USA. Cells were seeded at a density of $3 \times 10^{5}$ cells $/ \mathrm{mL}$ in $75-\mathrm{cm}^{2}$ suspension cell culture flasks and maintained and suspended in serum-free CD-CHO medium (Gibco, 10743011, USA) supplemented with $0.05 \%$ MSX (methionine sulphoximine) (Millipore, GSS-1015-F, USA) and 1\% HT supplement (a liquid mixture of sodium hypoxanthine $(10 \mathrm{mM})$ and thymidine $(1.6 \mathrm{mM}))(\mathrm{Gibco}, 11067-030$, USA). Cells were cultured in a humidified incubator with $5 \% \mathrm{CO}_{2}$ at $37{ }^{\circ} \mathrm{C}$. Cell line was routinely tested for mycoplasma contamination on a regular basis.

\section{Transient Transfection}

\section{Transfection of CHO Cells with DNA/PEI Complexes}

A PEI "Max" (Mw of 40,000 kDa, linear) (Polysciences, 24765-1, USA) stock solution of $1 \mathrm{mg} / \mathrm{mL}$ prepared in ultrapure water, neutralized to $\mathrm{pH} 7.0$ with $1 \mathrm{M} \mathrm{HCl}$, and incubated with shaking until completely dissolved. The PEI stock solution sterilized by filtration through a $0.22-\mu \mathrm{m}$ filter, and $1 \mathrm{~mL}$ aliquots were stored at $-86^{\circ} \mathrm{C}$. $\mathrm{CHO}$ cells in exponential phase were passaged to $1 \times 10^{6}$ cells $/ \mathrm{mL}$ in maintenance medium on the day prior to transfection. The PEI/ DNA complex was formed in OPTI-MEM I + GlutaMAX I (Gibco, 51985-030, USA) without serum to support complex formation. DNA was transferred to tubes at a final concentration of $0.5,1$, or $2 \mu \mathrm{g} / \mathrm{mL}$ in serum-free OPTI-MEM medium. PEI solution then added $1-8 \mu \mathrm{L} / \mathrm{mL}$ to the diluted DNA containing tubes drop by drop. The mixture was vortexed for $5 \mathrm{~s}$ and then incubated at room temperature for $30 \mathrm{~min}$. Finally, DNA/PEI mixture transferred to each well and plates were incubated with gentle shaking at $37{ }^{\circ} \mathrm{C}$ in an atmosphere with $5 \% \mathrm{CO}_{2}$ and 95\% humidity. For the next 7-day period, transfected $\mathrm{CHO}$ cells were observed with fluorescent microscope and cells were counted by ImageJ program.

\section{Transfection of CHO Cells with DNA/Lipofectamine 2000 Complexes}

CHO cells were transfected with lipofectamine-2000 (LPF) (Invitrogen, 11668019, USA) by using the product protocol. Briefly, $\mathrm{CHO}$ cells in exponential phase were passaged to $1 \times 10^{6}$ cells $/ \mathrm{mL}$ in maintenance medium on the day prior to transfection. The first mixture was prepared by adding $0.5,1$, or $2 \mu \mathrm{g} / \mathrm{mL}$ DNA to serum-free OPTI-MEM medium containing tubes. The mixture was vortexed for $5 \mathrm{~s}$ and incubated at room temperature for $15 \mathrm{~min}$. In a 
second mixture, Lipofectamine 2000 was transferred to different tubes by diluting $1-8 \mu \mathrm{L} / \mathrm{mL}$ of serum-free OPTI-MEM I + GlutaMAX I medium. LPF dilution was vortexed and incubated before getting mixed. After this period, these two tubes were mixed gently with each other and vortexed for $5 \mathrm{~s}$ just before the incubation at room temperature for $30 \mathrm{~min}$. Finally, DNA/ Lipofectamine mixture was transferred to each well and plates were incubated at $37{ }^{\circ} \mathrm{C}$ in an atmosphere with $5 \% \mathrm{CO}_{2}$ and $95 \%$ humidity for $3 \mathrm{~h}$ to allow the transfection. Cultures were then diluted with an equal volume of growth medium and were incubated with gentle shaking at $37{ }^{\circ} \mathrm{C}$ in an atmosphere with $5 \% \mathrm{CO}_{2}$ and $95 \%$ humidity. Transfected $\mathrm{CHO}$ cells were evaluated with fluorescent microscope and cells were counted by ImageJ program.

\section{Assessment of Transfection Efficiency by ImageJ}

Light and fluorescent microscope images of the cells were automatically counted by ImageJ 1.48 program. Briefly, the microscope photographs were color images (RGB), so they were converted to gray scale before proceeding: Edit-Options-Conversions steps were set and "scale when converting" option was checked. After the Image-Type-16bit (8bit) option was checked, the images become gray scale. Image-Adjust-Threshold $(C t r l+S h i f t+T)$ steps were set on gray scale images to highlight all of the structures we want to count. To highlight, either use the sliders or use the "set" button to type in a known range of pixel intensities (if you want to threshold a whole set of images the same way, for instance). Different highlight is given to each image when manual highlighting is performed with the slider. When "Dark background" is selected, the background will be highlighted with white, and cells will be in black color. Depending on the cell density, the slider was kept between 6 and 11 in fluorescent pictures and 65-80 in light pictures. After that, Process-Subtract background steps were set and "rolling ball" option was checked to determine and to destroy extra dirtiness after the highlight. Once the area highlighted "apply" option was clicked, this will create a binary version of the image with only two pixel intensities: black $=0$ and white $=255$. When we had particles that have merged together, Process-Binary-Watershed steps were set. This option can often (but not always) accurately cut them apart by adding a 1 pixel thick line where it feels the division should be. At this stage, the image must be 8-bit type, and this can be repeated a few times until black parts are falling apart. Finally, Analyze-Analyze Particles steps were set, and the images were inch "pixel units" option was checked and "Circularity: 0.001.00 " option was chosen. "Size" was set between "100-infinity" and "30-infinity" depending on the intensity of fluorescence in fluorescent images and cell morphology in light images. After all of the steps, "summarize" options were checked and cell numbers were counted.

\section{Staurosporine Treatment and Quantification of Cell Death}

Staurosporine (Sigma, S4400, USA) was used to induce apoptosis, which is effectively used in a wide variety of cell types [47]. Firstly, $1 \mathrm{mM}$ staurosporine stock solution was prepared by dissolving in DMSO (Millipore, 1.02952.2500, USA). Staurosporine stock solution was added to the transfected cell culture at a concentration of $1 \times 10^{6}$ cells $/ \mathrm{mL}$ at final concentration of $1 \mu \mathrm{M}$ after $48 \mathrm{~h}$ of transfection. Cells were incubated with staurosporine for $48 \mathrm{~h}$. Cell viabilities in the populations were analyzed by trypan blue dye exclusion assay (Applichem, A0668, Germany) on 3, 5, and 7 days after transfection. Also, after counting on the seventh day of culture, LIVE/DEAD cell viability assay kit (Molecular Probes, L3224, USA) was used to visualize cell viability according to manufacturer's instructions at eighth day of transfection which stains the live cells green and dead cells red. 


\section{Determination of Anti-TNF- $\alpha$ Quantity by ELISA}

Optimization of indirect enzyme-linked immunosorbent assay (ELISA) was done according to Nalbantsoy et al. to be used for determining the amount of mAbs produced [48]. Humira ${ }^{\circledR}$ (Abbott Laboratories, Abbott Park, IL), adalimumab, was used as a positive control which is the commercial biosimilar of the humanized anti-TNF- $\alpha$ antibody produced by the stable CHO cell line used in this study. First, recombinant TNF- $\alpha$ antigen (Gibco, PHC3011, USA) was prepared at the appropriate concentration $(100 \mathrm{ng} / 100 \mu \mathrm{L})$ in coating buffer $(0.05 \mathrm{M}$ carbonate-bicarbonate buffer (CBB), pH 9.6), then added to each well of 96-well immunoplate (PolySorp Nunc-Immuno plate, Sigma, M0661, USA) and incubated at $+4{ }^{\circ} \mathrm{C}$ overnight. The next day, each well was washed $(100 \mu \mathrm{L} /$ well $) 3 \times 5$ min with T-PBS $(1 \times$ phosphate buffer solution containing $0.05 \%$ Tween 20 ) solution. After blocking was made $30 \mathrm{~min}$ at room temperature in $0.5 \%$ T-PBS $(w / v)$ with BSA solution $(200 \mu \mathrm{L} /$ well $)$, wells were washed $(100 \mu \mathrm{L} / w e l l)$ as before. At the end of this time, the appropriate dilutions of the samples were added $(100 \mu \mathrm{L} /$ well $)$ and incubated $1 \mathrm{~h}$ at room temperature, then wells were washed again. After the conjugate solution (1:10,000 goat anti-human IgG conjugated with HRP-whole antibody diluted in 1× PBS) (Invitrogen-Novex, 10691234, USA) was added (100 $\mu \mathrm{L} /$ well) and incubated for $1 \mathrm{~h}$ at room temperature, washing process was performed one more time. Finally, $100 \mu \mathrm{L}$ substrate solution which consists of OPD (o-Phenylenediamine dihydrochloride; Sigma, P8412, USA) at a final concentration of $0.4 \mathrm{mg} / \mathrm{mL}$ in $75 \mathrm{~mL}$ $0.05 \mathrm{M}$ phosphate-citrate buffer and $30 \mu \mathrm{L}$ of $30 \% \mathrm{H}_{2} \mathrm{O}_{2}$ was added, and incubated for $30 \mathrm{~min}$ at room temperature at dark. After the incubation, stop solution (97-98\% $3 \mathrm{M}$ $\left.\mathrm{H}_{2} \mathrm{SO}_{4}\right)$ was added $(50 \mu \mathrm{L} /$ well $)$ and plates were read at $450 \mathrm{~nm}$ wavelength by spectrophotometer (SpectraMax 190 Molecular Devices, USA). mAb titers were calculated by using the following Eq. [49]:

$$
Y(\text { absorbance@450nm })=0.06170 \times X(\text { anti }-\mathrm{TNF} \alpha, \mathrm{mg} / \mathrm{mL})+0.07114
$$

Also, product yield coefficients $\left(Y_{\mathrm{p} / \mathrm{x}}\right)$ were calculated by plotting anti-TNF- $\alpha$ production (ng) against cell number in the cultures. In this calculation, logarithmic cell growth phase (between days 3 and 5 of culture) was considered.

\section{Statistical Analysis}

All assays were repeated at least three times to ensure reproducibility and three replicates of each group were performed in each test. Statistical significance of differences between two groups was evaluated by Student's unpaired $t$ test and multi-group comparisons were performed using two-way analysis of variance (ANOVA) followed by Tukey's post hoc test by Prism 6.0 (GraphPad Software, Inc., San Diego, CA, USA). Data are presented as mean (SD) and the level of $p<0.05$ was considered as statistically significant.

\section{Results}

\section{Transfection of CHO Cells with DNA/PEI Complexes}

Before evaluation of the potential positive effects of Bcl-xL transfection on anti-TNF- $\alpha$ production, transfection efficacy of $\mathrm{CHO}$ cells by either Bcl-xL bearing or not bearing 
pIRES2EGFP-PEI complexes were optimized. It is known that transfection efficiency of suspended CHO cells with PEI is greatly affected by the ratio of DNA:PEI and DNA concentration. In this research, DNA:PEI ratios which were chosen for the experimental sets include 1:1, 1:2, 1:3, 1:4, 1:5, 1:6, 1:7, and 1:8 according to the previous studies [41, 50-53]. Fractional values (i.e., 1:1.8, 1:3.9, 1:4.5) were selected by calculating nitrogen-phosphorus ratios [54]. As for DNA concentration, $0.5,1$, and $2 \mu \mathrm{g} / \mathrm{mL}$ were evaluated in the procedures of transfection using PEI. According to the results, when $\mathrm{CHO}$ cells were transfected with $0.5 \mu \mathrm{g} / \mathrm{mL}$ DNA and DNA:PEI ratios of 1:5, transfected cells expressing EGF were hardly observed (Fig. 1). Furthermore, increasing the ratio of DNA:PEI did not increase the transfection rate due to the small amount of DNA (Fig. 2). However, when the amount of DNA was used as $1 \mu \mathrm{g} / \mathrm{mL}$ and above, a large number of transfected cells were observed for all DNA:PEI ratios. Transfection efficiencies (percentage of EGFP expressing cells) were quantified through cell counting with ImageJ software. According to these quantitation data,

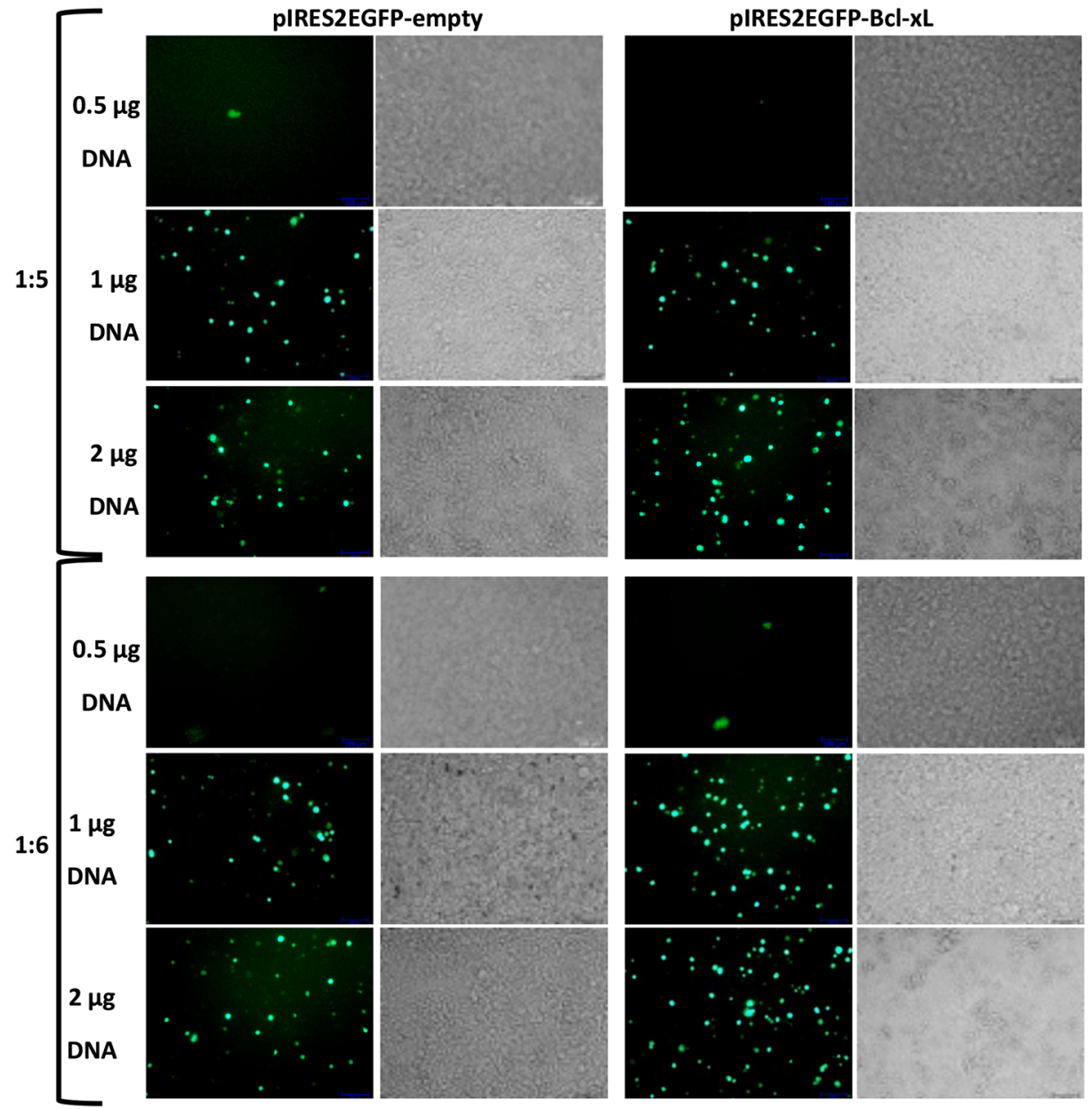

Fig. 1 Fluorescence and light microscopy images of CHO cells non-transfected (control) and transfected by 0.5 , 1, or $2 \mu \mathrm{g}$ pIRES2EGFP-empty or pIRES2EGFP-Bcl-xL $48 \mathrm{~h}$ after treatment with DNA-PEI complexes at the ratios of 1:5 and 1:6. (scale bar: $100 \mu \mathrm{m}$ ) 


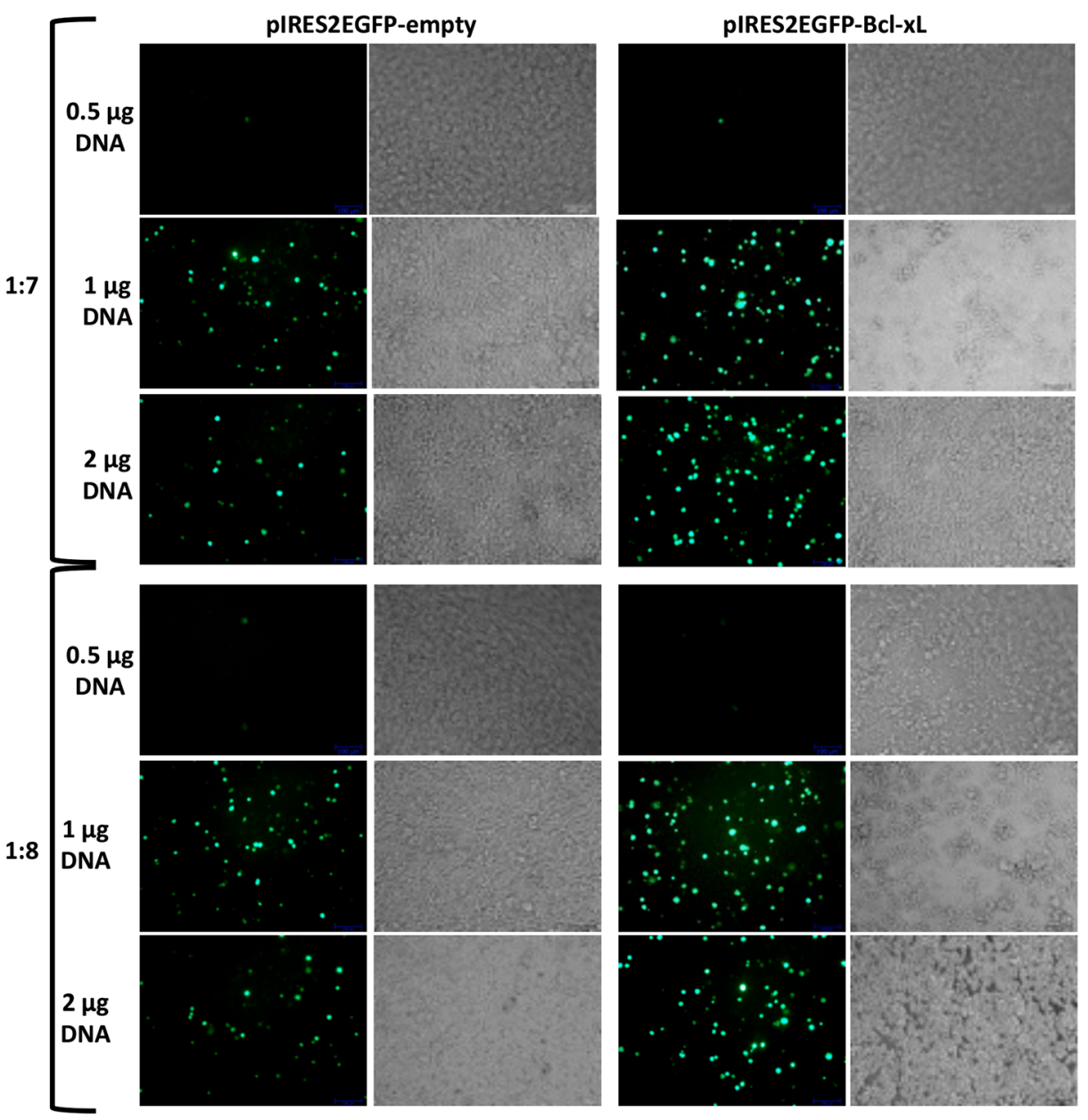

Fig. 2 Fluorescence and light microscopy images of CHO cells non-transfected (control) and transfected by 0.5 , 1, or $2 \mu \mathrm{g}$ pIRES2EGFP-empty or pIRES2EGFP-Bcl-xL $48 \mathrm{~h}$ after treatment with DNA-PEI complexes at the ratios of 1:7 and 1:8. (scale bar: $100 \mu \mathrm{m}$ )

transfection efficiency of cells treated with $1 \mu \mathrm{g} / \mathrm{mL}$ DNA was significantly higher than cells treated with $0.5 \mu \mathrm{g} / \mathrm{mL}$ DNA for DNA:PEI ratios of 1:2 $(p<0.01), 1: 4(p<0.001), 1: 6,1: 7$, and 1:8 $(p<0.0001)$ (Fig. 3a). Transfection efficiencies were increased by 283,447 , and $400 \%$ compared to experimental groups that DNA concentration of $0.5 \mu \mathrm{g} / \mathrm{mL}$ was used when DNA:PEI ratios of 1:6, 1:7, and 1:8 were used, respectively, with DNA concentration of $1 \mu \mathrm{g} /$ $\mathrm{mL}$. Moreover, it was seen that different DNA:PEI ratios did not significantly affect transfection efficiencies except for DNA:PEI ratio of 1:8 in the experiments of transfection with $0.5 \mu \mathrm{g}$ DNA (Fig. 3a). Transfection efficiency of cells transfected with DNA:PEI ratio of 1:8 and with $0.5 \mu \mathrm{g} / \mathrm{mL}$ DNA was higher only than cells treated with ratios of 1:1.8, 1:2, 1:4, and 1:4.5 $(p<0.05)$ with the transfection efficiency of $1.14 \%$. Due to these results, $1 \mu \mathrm{g} / \mathrm{mL}$ DNA concentration resulting higher transfection efficiencies compared to $0.5 \mu \mathrm{g} / \mathrm{mL}$ was chosen for following experiments. The results showed that transfection efficiencies of cell groups treated by DNA:PEI ratios of 1:6, 1:7, and 1:8 were significantly higher than all other groups when 

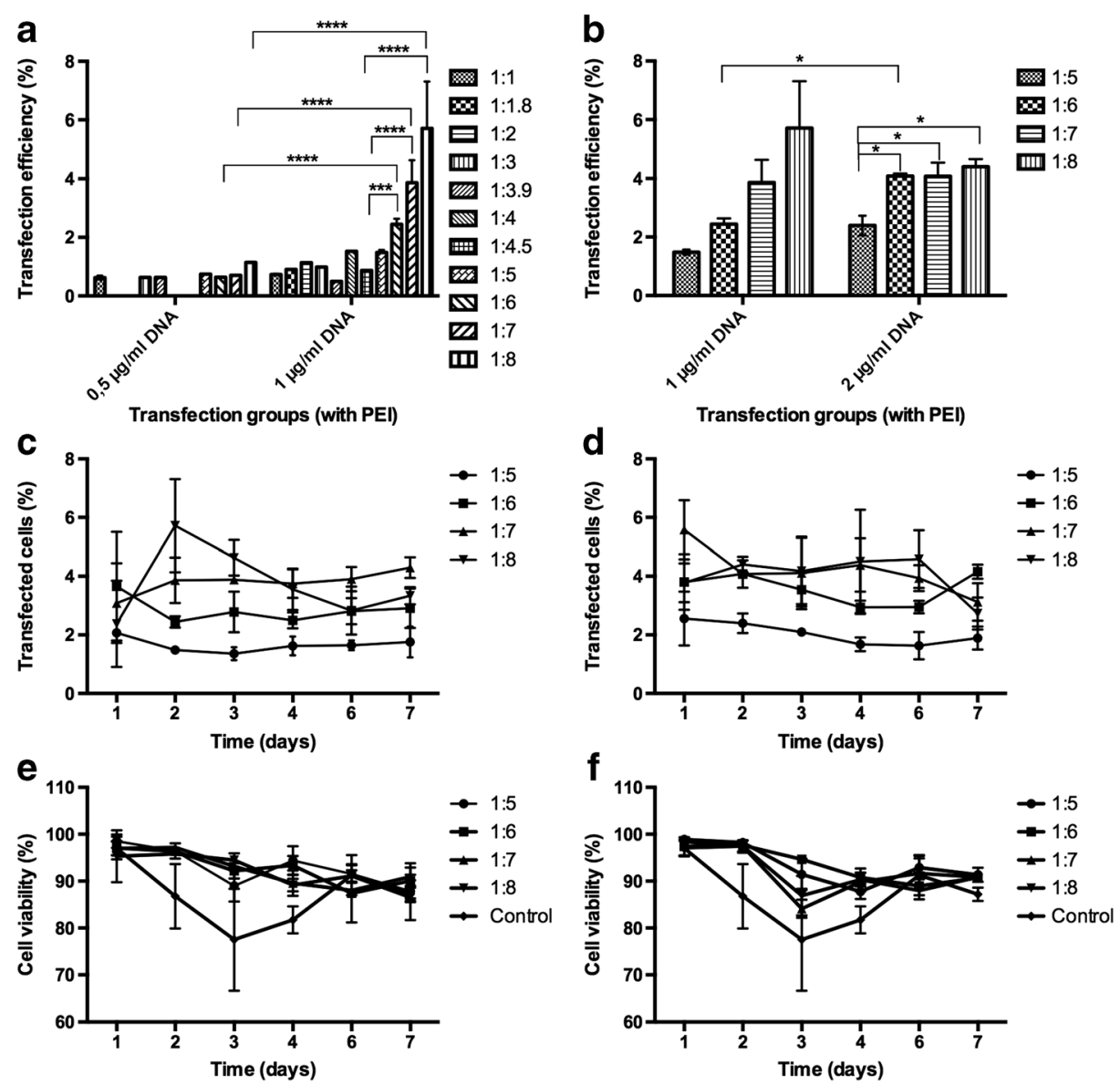

Fig. 3 Transfection efficiencies of cells transfected a by 0.5 or $1 \mu \mathrm{g}$ pIRES2EGFP-Bcl-xL $48 \mathrm{~h}$ after treatment with DNA-PEI complexes at the DNA:PEI ratios of 1:1 to 1:8 and b by 1 or $2 \mu \mathrm{g}$ pIRES2EGFP-Bcl-xL $48 \mathrm{~h}$ after treatment with DNA-PEI complexes at the ratios of 1:5 to 1:8. The change of percentage of cells transfected by $\mathbf{c} 1 \mu \mathrm{g}$ and $\mathbf{d} 2 \mu \mathrm{g}$ pIRES2EGFP-Bcl-xL after treatment with DNA-PEI complexes at the ratios of 1:5 to 1:8 from day to day. The change of percentage of cell viabilities transfected by e $1 \mu \mathrm{g}$ and $\mathbf{f} 2 \mu \mathrm{g}$ pIRES2EGFP-Bcl$\mathrm{xL}$ after treatment with DNA-PEI complexes at the ratios of 1:5 to 1:8 from day to day (control group was nontransfected cells). All percentages of transfected cells were calculated by evaluation of GFP expressing cells in the population by observation under fluorescent microscope. Significant differences between experimental groups are represented in the graph as $* p<0.05$, *** $p<0.001$, **** $p<0.0001$. Data are presented as mean $\pm \mathrm{SD}$. Two-way ANOVA followed by Tukey's post hoc test

$1 \mu \mathrm{g} / \mathrm{mL}$ DNA was used for transfection with the transfection efficiency of $2.44,3.87$, and $5.72 \%$, respectively. Therefore, these three DNA:PEI ratios 1:6, 1:7, and 1:8 and additionally DNA:PEI ratio of 1:5 were chosen for the following investigations to assess the effect of transfection with plasmid bearing Bcl-xL on cell viability. Moreover, besides $1 \mu \mathrm{g} / \mathrm{mL}$ DNA concentration, $2 \mu \mathrm{g} / \mathrm{mL}$ DNA was used to test whether transfection efficiency was increased or not with these chosen DNA:PEI ratios. As a result of these evaluations, it was observed that transfection efficiency of cell group transfected by $2 \mu \mathrm{g} / \mathrm{mL}$ DNA was significantly higher than cell group transfected by $1 \mu \mathrm{g} / \mathrm{mL}$ DNA only for the cell group transfected by DNA:PEI ratio of 1:6 $(p<0.05)$ with an increase of transfected cell ratio by $57.7 \%$, and the difference of 
transfection efficiencies between cells transfected by 1 and $2 \mu \mathrm{g} / \mathrm{mL}$ DNA was not significant for other transfection groups (1:7 and 1:8) (Fig. 3b). In spite of the fact that difference of transfection efficiencies between cell groups transfected with these two DNA concentrations were not consistent for all tested DNA:PEI ratios, transfection by $2 \mu \mathrm{g} / \mathrm{mL}$ DNA was chosen as a more promising concentration in respect to efficiency of transfection for further analyses. Moreover, transfection efficiency of cell groups transfected by DNA:PEI ratio of 1:5 was significantly lower than other three transfected groups both for groups transfected with 1 and $2 \mu \mathrm{g} / \mathrm{mL}$ DNA concentrations (Fig. 3b). Therefore, DNA:PEI ratio of 1:5 was excluded for following examinations consisting of analyses of apoptotic tendency of cells transfected with Bcl-xL-bearing plasmid after staurosporine treatment and production of anti-TNF- $\alpha$ by these cells. However, there was no any significant difference between transfection efficiencies of cell groups transfected by DNA:PEI ratio of 1:6, 1:7, and 1.8 when $2 \mu \mathrm{g} / \mathrm{mL}$ DNA concentration was used to transfect cells. Therefore, despite insignificancy of transfection efficiency difference between cell groups transfected with these three ratios, 1:6 and 1:8 were used in further analyses as lowest and highest DNA:PEI ratios to pursue effects of these ratios. The results also indicated that when cells transfected with $1 \mu / \mathrm{mL}$ DNA, expression of the plasmid bearing GFP besides Bcl-xL was continued during 7 days without any significant and continuous decrease (Fig. 3c). As expected, no decrease in ratio of EGF expressing cells was observed when the amount of DNA was increased to $2 \mu \mathrm{g} / \mathrm{mL}$ for transfection of cells as well (Fig. 3d).

According to the results presented in Fig. 3e, viabilities of cells were significantly higher in cell groups transfected by Bcl-xL-bearing plasmid compared to non-transfected control group at second, third, and fourth day after transfection for cells transfected by $1 \mu \mathrm{g} / \mathrm{mL}$ DNA concentrations. In addition, while cell viability in non-transfected group were decreasing day by day until the third day of culture due to adaptation of fresh culture condition, cell viabilities in all transfected groups were not significantly decreased day by day (Fig. 3e). As expected, a similar trend was observed when two times more DNA amount was used to transfect cells (Fig. 3f). In brief, in light of the above data, DNA:PEI ratios of 1:6 and 1:8 with using $2 \mu \mathrm{g} / \mathrm{mL}$ DNA concentration were selected for transfections in further examinations with PEI reagent because of the fact that these transfection procedures provided higher transfection efficiencies (4.08 and 4.4\%) compared to other transfected groups $48 \mathrm{~h}$ after transfection and higher cell viabilities (approximately an increase by $12 \%, 48 \mathrm{~h}$ after transfection) compared to nontransfected control group between second and fourth days of transfection.

\section{Transfection of CHO Cells with DNA/Lipofectamine 2000 Complexes}

As in the evaluation of efficiency in transfection with PEI, before evaluation of the effects of $\mathrm{Bcl}-\mathrm{xL}$ transfection on anti-TNF- $\alpha$ production, the proper conditions for transfection of $\mathrm{CHO}$ cells by either Bcl-xL bearing or not bearing pIRES2EGFP-Lipofectamine (LPF) complexes were examined. For transfection of CHO cells with LPF, different DNA:LPF ratios (1:1, 1:1.8, $1: 2,1: 3,1: 3 . .9,1: 4,1: 4.5,1: 5,1: 6,1: 7,1: 8)$ were used correspondingly. Fluorescent microscopy observation revealed that the use of $0.5 \mu \mathrm{g} / \mathrm{mL}$ DNA was insufficient to transfect $\mathrm{CHO}$ cells via LPF for DNA:LPF ratio of 1:1.8. When the amount of DNA was increased to 1 and $2 \mu \mathrm{g} / \mathrm{mL}$, a large number of transfected cells were observed (Fig. 4). The quantification of the images showed that transfection efficiency of cells treated with $1 \mu \mathrm{g}$ DNA was significantly higher than cells treated with $0.5 \mu \mathrm{g}$ DNA for DNA:LPF ratios except for transfection at ratios of 1:3.9, 1:4.5, 1:5, and 1:6 $(p<0.0001)$ (Fig. 5a). Based on these results, transfection with 
$1: 1.8$
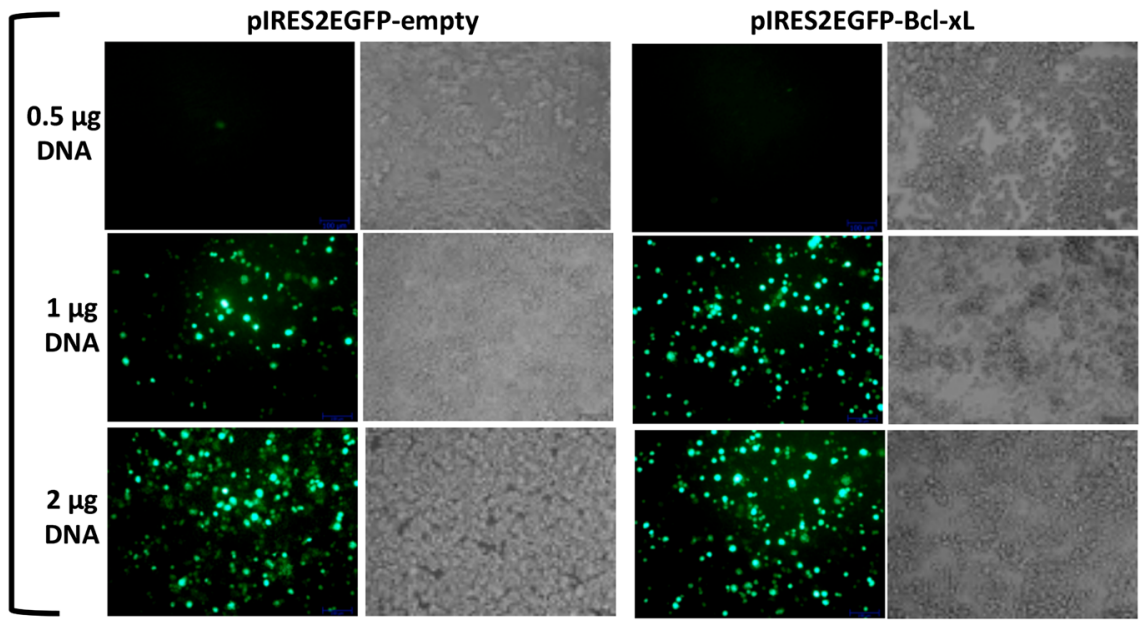

Fig. 4 Fluorescence and light microscopy images of CHO cells non-transfected (control) and transfected by 0.5 , 1, or $2 \mu \mathrm{g}$ pIRES2EGFP-empty or pIRES2EGFP-Bcl-xL $48 \mathrm{~h}$ after treatment with DNA-Lipofectamine (LPF) complexes at the ratio of 1:1.8. (scale bar: $100 \mu \mathrm{m})$

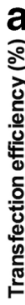

व

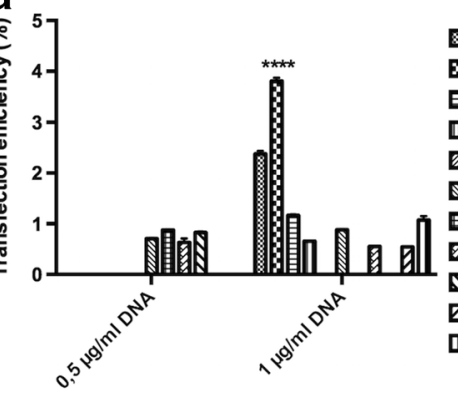

Transfection groups (with LPF)

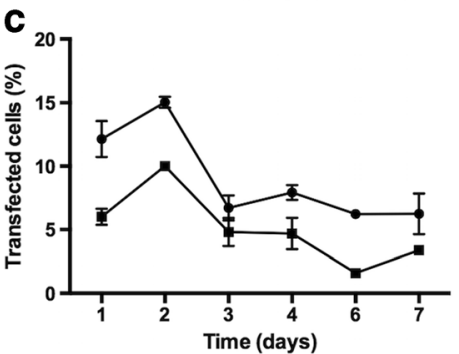

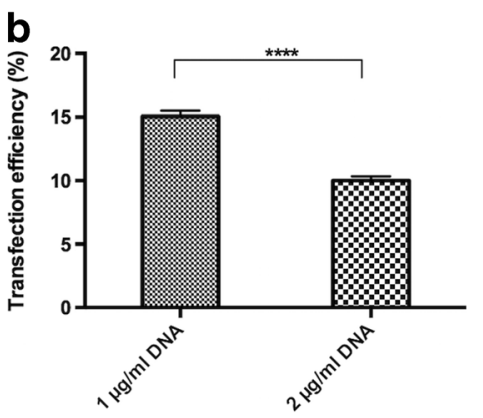

Transfection groups (with LPF)

d

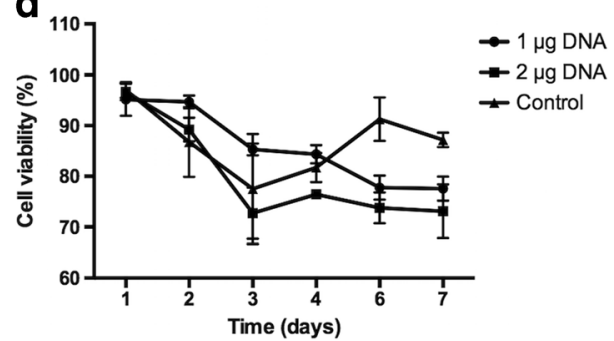

Fig. 5 Transfection efficiencies of cells transfected a by 0.5 or $1 \mu \mathrm{g}$ pIRES2EGFP-Bcl-xL $48 \mathrm{~h}$ after treatment with DNA-LPF complexes at the DNA:LPF ratios of 1:1 to $1: 8$ and $\mathbf{b}$ by 1 or $2 \mu \mathrm{g}$ pIRES2EGFP-Bcl-xL $48 \mathrm{~h}$ after treatment with DNA:LPF complex at ratio of 1:1.8. $\mathbf{c}$ The change of percentage of cells transfected by 1 and $2 \mu \mathrm{g}$ pIRES2EGFP-Bcl-xL after treatment with DNA-LPF complexes at the DNA:LPF ratio of 1:1.8 from day to day. $\mathbf{d}$ The change of percentage of cell viabilities transfected by 1 and $2 \mu \mathrm{g}$ pIRES2EGFP-Bcl-xL after treatment with DNA-LPF complexes at the DNA:LPF ratio of 1:1.8 from day to day (control group was non-transfected cells). All percentages of transfected cells were calculated by evaluation of GFP expressing cells in the population by observation under fluorescent microscope. Significant differences between experimental groups are represented in the graph as $* * * * p<0.0001$. Data are presented as mean \pm SD. a, c, d Two-way ANOVA followed by Tukey's post hoc test. b Two-tailed unpaired Student's $t$ test 
$1 \mu \mathrm{g} / \mathrm{mL}$ DNA concentration was used to choose efficient DNA:LPF ratios. According to Fig. 5a, transfection by using DNA:LPF ratio of 1:1.8 gave the most efficient transfection result with a significant difference from all other groups $(p<0.0001)$. To test whether increase of DNA concentration was influential or not on transfection efficiencies, besides $1 \mu \mathrm{g} / \mathrm{mL}$ DNA concentration, $2 \mu \mathrm{g} / \mathrm{mL}$ was also used. However, transfection with increased DNA concentration did not result in positive effect on transfection efficiency (Fig. 5b). According to the results presented in Fig. 5b transfection with DNA:LPF ratio of 1:1.8 and $1 \mu \mathrm{g} / \mathrm{mL}$ DNA concentration gave higher transfection efficiency with $15.03 \%$ (1.5-fold) compared to $1 \mu \mathrm{g} / \mathrm{mL}$ DNA concentration. Due to this reason, transfection by $1 \mu \mathrm{g}$ DNA was chosen for the most efficient transfection. Also, the results showed that expression of the plasmid bearing also GFP was continued during 7 days without significant decrease except for decrease between number of GFP expressed cells at second day of culture and third day of culture $(p<0.0001)$ (Fig. 5c). Transfection procedure by using 1:1.8 DNA:LPF ratio and $1 \mu \mathrm{g} / \mathrm{mL}$ DNA concentration did not cause a significant decrease in cell viability till the sixth day of culture (Fig. 5d). According to the results shown in Fig. 5d, viability of cells was significantly higher in cell group transfected with Bcl-xL-bearing plasmid compared to non-transfected control group at second, third, and fourth day after transfection with $1 \mu \mathrm{g} / \mathrm{mL}$ DNA concentration (with an increase of $9.16,10.06$, and $3.22 \%$, respectively).

\section{Transfection of CHO Cells with DNA/Lipofectamine 2000 Complexes}

As in the evaluation of efficiency in transfection with PEI, before evaluation of the effects of $\mathrm{Bcl}-\mathrm{xL}$ transfection on anti-TNF- $\alpha$ production, the proper conditions for transfection of $\mathrm{CHO}$ cells by either Bcl-xL bearing or not bearing pIRES2EGFP-Lipofectamine (LPF) complexes were examined. For transfection of CHO cells with LPF, different DNA:LPF ratios (1:1, 1:1.8, $1: 2,1: 3,1: 3 . .9,1: 4,1: 4.5,1: 5,1: 6,1: 7,1: 8)$ were used correspondingly. The results showed that transfection efficiency of cells treated with $1 \mu \mathrm{g}$ DNA was significantly higher than cells treated with $0.5 \mu \mathrm{g}$ DNA for DNA:LPF ratios except for transfection at ratios of 1:3.9, 1:4.5, 1:5, and 1:6 ( $p<0.0001)$ (Figs. 4 and 5a). Based on these results, transfection with $1 \mu \mathrm{g} / \mathrm{mL}$ DNA concentration was used to choose efficient DNA:LPF ratios. According to Fig. 5a, transfection by using DNA:LPF ratio of 1:1.8 gave the most efficient transfection result with a significant difference from all other groups $(p<0.0001)$. To test whether increase of DNA concentration was influential or not on transfection efficiencies, besides $1 \mu \mathrm{g} / \mathrm{mL}$ DNA concentration, $2 \mu \mathrm{g} / \mathrm{mL}$ was also used. However, transfection with increased DNA concentration did not result in positive effect on transfection efficiency (Figs. 4 and 5b, c). According to the results presented in Fig. 3b, transfection with DNA:LPF ratio of 1:1.8 and $1 \mu \mathrm{g} / \mathrm{mL}$ DNA concentration gave higher transfection efficiency with $15.03 \%$ (1.5-fold) compared to $1 \mu \mathrm{g} / \mathrm{mL}$ DNA concentration. Due to this reason, transfection by $1 \mu \mathrm{g}$ DNA was chosen for the most efficient transfection. Also, the results showed that expression of the plasmid bearing also GFP was continued during 7 days without significant decrease except for decrease between number of GFP expressed cells at second day of culture and third day of culture $(p<0.0001)$ (Fig. 5c). Transfection procedure by using 1:1.8 DNA:LPF ratio and $1 \mu \mathrm{g} / \mathrm{mL}$ DNA concentration did not cause a significantly decrease in cell viability till the sixth day of culture (Fig. 5d). According to the results shown in Fig. 5d, viability of cells was significantly higher in cell group transfected with Bcl-xL-bearing plasmid compared to non-transfected control group at second, third, and fourth day after transfection with $1 \mu \mathrm{g} / \mathrm{mL}$ DNA concentration (with increase of $9.16,10.06$, and $3.22 \%$, respectively). 


\section{Staurosporine Treatment and Quantification of Cell Death}

Staurosporine which is a protein kinase inhibitor was reported as an inducer of apoptosis in several cell types $[47,55]$. Considering optimal transfection conditions stated above, staurosporine treatment experiments were conducted in order to examine the effect of transfection with Bcl-xL on anti-apoptotic feature of the cell populations. For this examination, CHO cells were transfected by pIRES2EGFP-empty (as control) or pIRES2EGFP-Bcl-xL by using $2 \mu \mathrm{g} / \mathrm{mL}$ DNA and the DNA:PEI ratios of 1:6 and 1:8 for transfection with PEI and by using $1 \mu \mathrm{g} / \mathrm{mL}$ DNA and the DNA:LPF ratio of 1:1.8 for transfection with LPF. Transfected cells were treated by staurosporine $48 \mathrm{~h}$ after transfection to induce apoptosis, and viability of cells was examined by trypan blue dye exclusion assay 3, 5, and 7 days after transfection and visualized by LIVE/DEAD assay 8 days after transfection (Fig. 6). It was shown that $\mathrm{CHO}$ cells transfected by Bcl-xL-bearing plasmid had significantly higher cell viability than cells transfected by empty vector $24 \mathrm{~h}$ after induction of apoptosis by staurosporine $(p<0.0001)$ (Fig. 7a). Likewise viability of CHO cells transfected by Bcl-xL-bearing plasmid via LPF were higher compared to control cells transfected by empty vector $24 \mathrm{~h}$ after staurosporine treatment $(p<0.0001)$ (Fig. 7b). According to the results shown in Fig. 7a, viability of CHO cells transfected with Bcl-xL-bearing plasmid:PEI complex with ratios of 1:6 and 1:8 were enhanced compared to viability of cells transfected by empty vector $24 \mathrm{~h}$ after induction of apoptosis by staurosporine with increases of cell viability by 25.45 and $39.89 \%$, respectively. As for transfection with Bcl-xL-bearing plasmid:LPF complex with ratio of 1:1.8, cell viability was enhanced by $38.67 \% 24 \mathrm{~h}$ after induction of apoptosis (Fig. $7 \mathrm{~b}$ ).

\section{Determination of Anti-TNF- $\alpha$ Quantity Produced by the CHO Cell ELISA}

To determine whether transfection by Bcl-xL-bearing plasmid increase anti-TNF- $\alpha$ production in $\mathrm{CHO}$ cells or not, determined optimal transfection conditions were used. For determination of anti-TNF- $\alpha$ production, CHO cells were transfected by pIRES2EGFP-empty (as control) or pIRES2EGFP-Bcl-xL by using $2 \mu \mathrm{g} / \mathrm{mL}$ DNA and the DNA:PEI ratios of 1:6 and 1:8 for transfection with PEI and by using $1 \mu \mathrm{g} / \mathrm{mL}$ DNA and the DNA:LPF ratio of 1:1.8 for transfection with LPF and production of anti-TNF- $\alpha$ was determined by ELISA. It was shown that $\mathrm{CHO}$ cells transfected with Bcl-xL-bearing plasmid had produced significantly higher level of anti-TNF- $\alpha$ compared to cells transfected by empty vector. According to the results, at seventh day of transfection, CHO cells transfected with Bcl-xL-bearing plasmid by PEI at 1:6 ratio $(p<0.0001)$ and $1: 8$ ratio $(p<0.01)$ and by LPF at $1: 1.8$ ratio $(p<0.0001)$ produced significantly higher level of anti-TNF- $\alpha$ in comparison with $\mathrm{CHO}$ cells transfected with empty plasmid by the same transfection procedures. While the production of anti-TNF- $\alpha$ in $\mathrm{CHO}$ cells was $134 \mathrm{mg} / \mathrm{L}$ after transfection with empty plasmid, the production increased up to $215 \mathrm{mg} / \mathrm{L}$ after transfection with Bcl-xL-bearing plasmid:PEI reagent at a ratio of 1:6 with a 1.60 -fold increase. In addition, when $\mathrm{CHO}$ cells transfected with Bcl-xL-bearing plasmid:PEI reagent ratio of 1:8, production of anti-TNF- $\alpha$ was enhanced from 123.17 to $147.17 \mathrm{mg} / \mathrm{L}$ with a 1.19-fold increase. As a control of transfection using LPF reagent, the production of antiTNF- $\alpha$ was increased from 96 up to $198 \mathrm{mg} / \mathrm{L}$ with 2.07-fold increase (Fig. 8a). In addition, product yield coefficients $\left(Y_{\mathrm{p} / \mathrm{x}} ; \mathrm{ng} / \mathrm{cell}\right)$ for anti-TNF- $\alpha$ production were calculated taking into account the logarithmic growth phase of the cells. The results indicated that for all transfection methods, cells transfected with Bcl-xL had statistically higher $Y_{\mathrm{p} / \mathrm{x}}$ values than cells transfected with empty vector. These results also suggest that the cells transfected with LPF showed the 


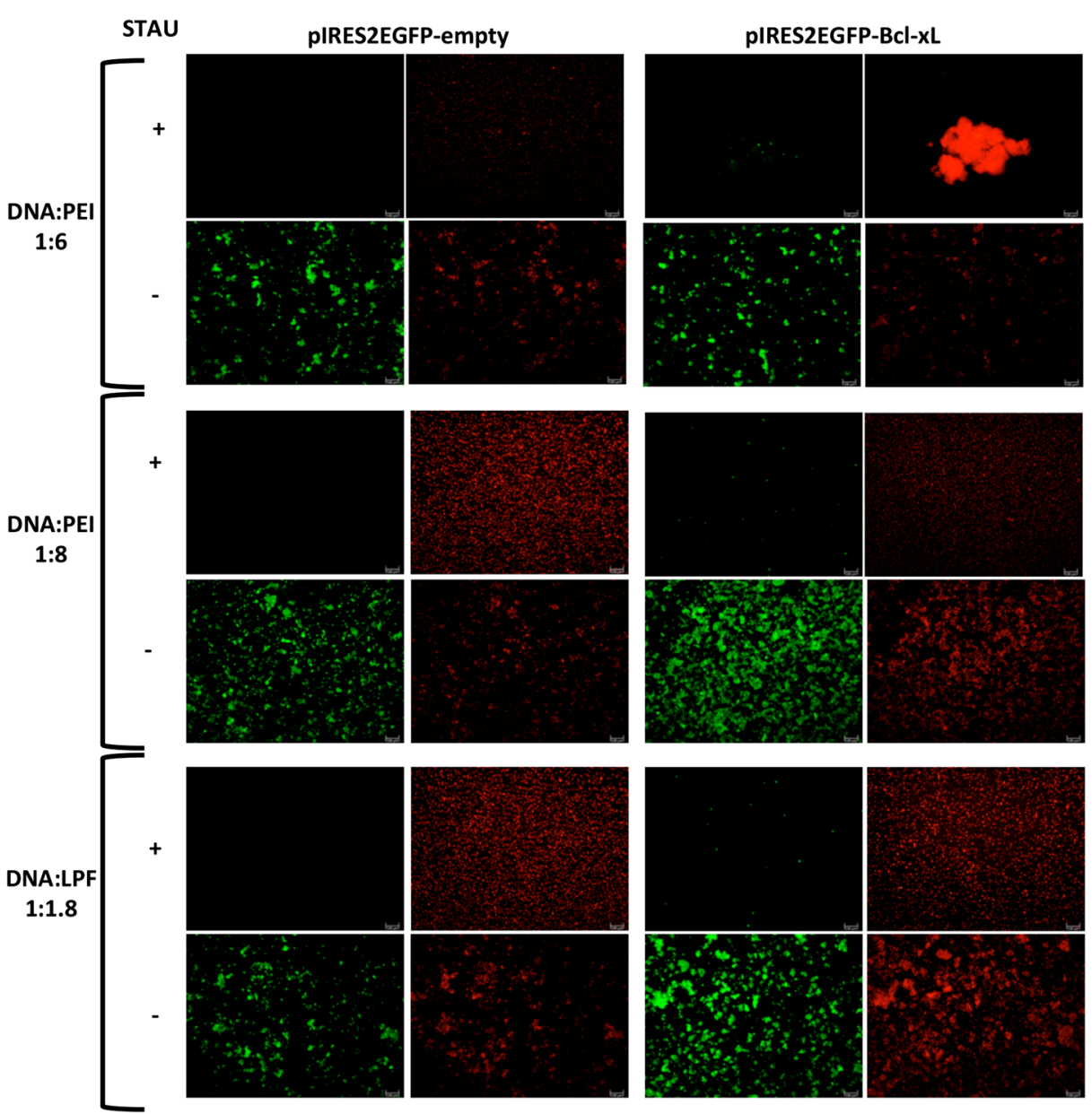

Fig. 6 Fluorescence microscopy images of $\mathrm{CHO}$ cells, non-transfected (control) and transfected by pIRES2EGFP-empty or pIRES2EGFP-Bcl-xL by LIVE/DEAD® viability/cytotoxicity assay. The transfection by PEI was carried out by using $2 \mu \mathrm{g} / \mathrm{mL}$ DNA and the DNA:PEI ratios of 1:6 and 1:8; the transfection by LPF was carried out by using $1 \mu \mathrm{g} / \mathrm{mL}$ DNA and the DNA:PEI ratio of 1:1.8. Transfected cells also were treated by staurosporine (STAU) $48 \mathrm{~h}$ after transfection to induce apoptosis and viability of cells was observed under fluorescence microscope 8 days after transfection. Live cells fluoresce green and dead cells with compromised membranes fluoresce red. (scale bar: $100 \mu \mathrm{m})$

highest $Y_{\mathrm{p} / \mathrm{x}}$ value with $0.098 \mathrm{ng} / \mathrm{cell}$. No statistically significant change was observed between cell groups transfected by the empty vector (Fig. 8 b).

\section{Discussion}

During the recent years TGE has been under investigation for many researchers in order to produce proteins in mammalian cell hosts in a short period of time and cost-effectively [8, 43, 56]. In spite of that PEIs are efficient and cost-effective transfection reagents, they provide lower protein expression for each gene copy delivered than that of viral vectors [57, 58]. Delafosse et al. reported that the use of PEImax to transiently transfect $\mathrm{CHO}$ cells provided 

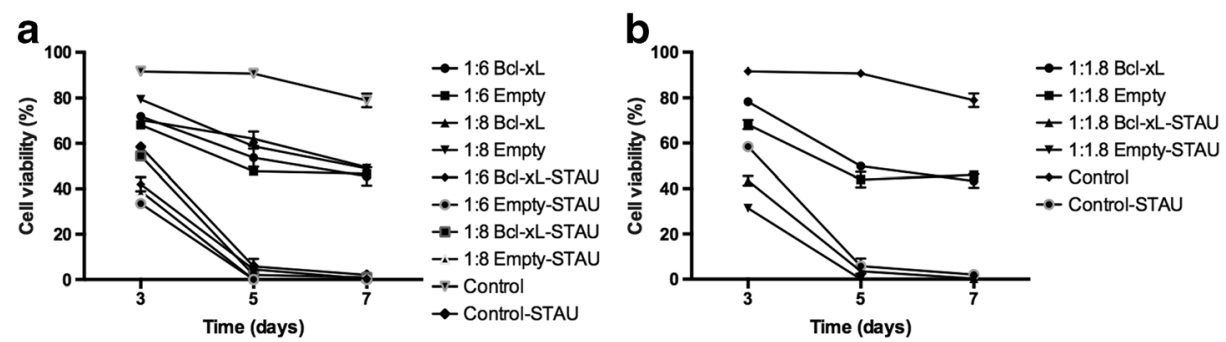

Fig. 7 a, $\mathbf{b}$ The change of percentage of cell viabilities transfected by pIRES2EGFP-Empty or pIRES2EGFPBcl-xL after treatment with DNA-PEI complexes at the ratio of 1:6 or 1:8 with $2 \mu \mathrm{g} / \mathrm{mL}$ DNA or DNA-LPF complexes at the ratio of 1:1.8 with $1 \mu \mathrm{g} / \mathrm{mL}$ DNA. Transfected cells also were treated by STAU $48 \mathrm{~h}$ after transfection to induce apoptosis and viability of cells were evaluated by trypan blue dye exclusion assay 3,5 , and 7 days after transfection. Data are presented as mean \pm SD. Two-way ANOVA followed by Tukey's post hoc test
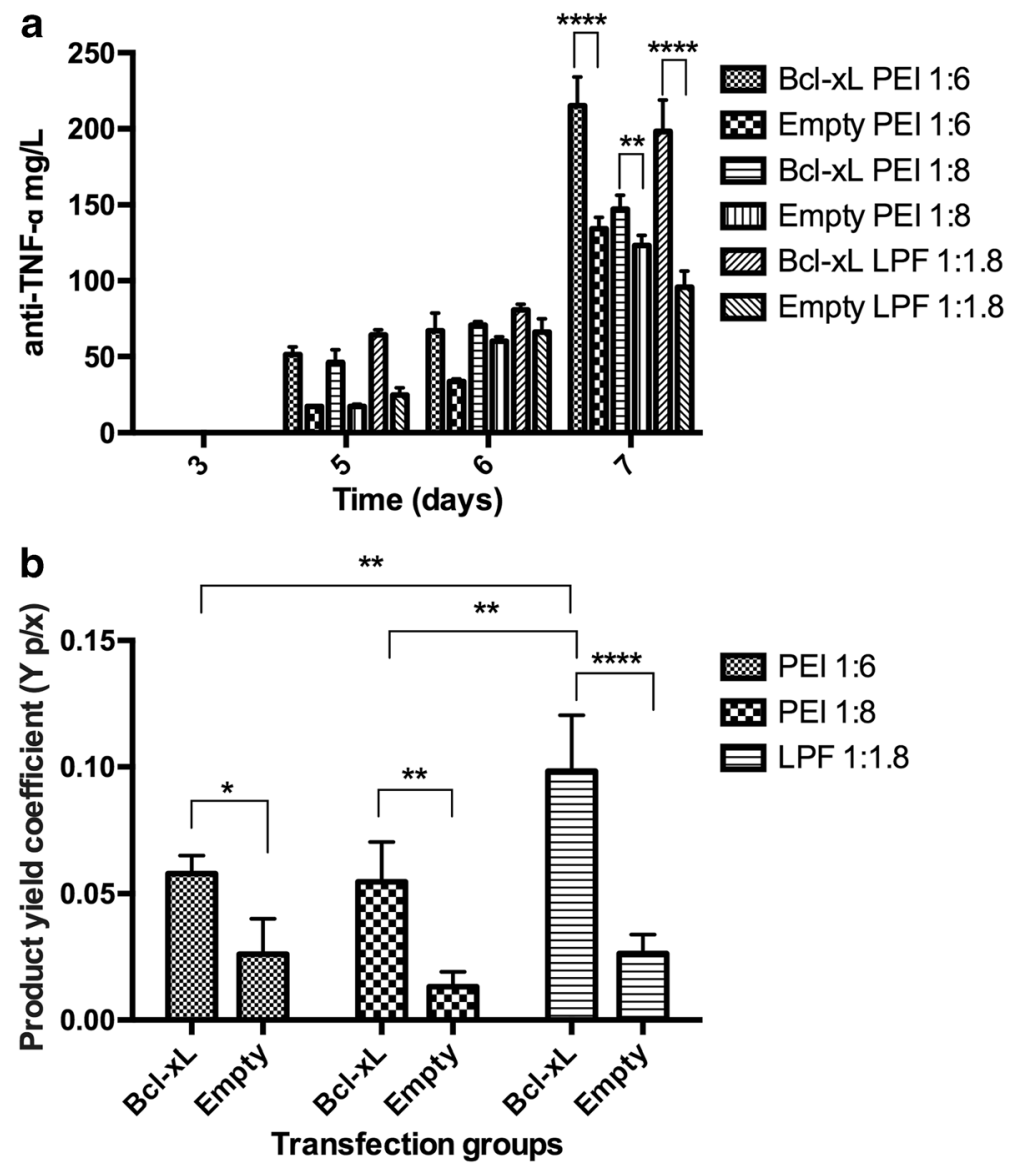

Fig. 8 a ELISA analysis of anti-TNF- $\alpha$ expression in cells transfected by pIRES2EGFP-empty or pIRES2EGFP-Bcl-xL after treatment with DNA-PEI complexes at the ratio of 1:6 or 1:8 with $2 \mu \mathrm{g} / \mathrm{mL}$ DNA or DNA-LPF complexes at the ratio of 1:1.8 with $1 \mu \mathrm{g} / \mathrm{mL}$ DNA. b Product yield coefficients $\left(Y_{\mathrm{p} / \mathrm{x}} ; \mathrm{ng} / \mathrm{cell}\right)$ for anti-TNF- $\alpha$ production by these cells. Significant differences between experimental groups are represented in the graph as $* p<0.05, * * p<0.01, * * * * p<0.0001$. Data are presented as mean $\pm \mathrm{SD}$. Two-way ANOVA followed by Tukey's post hoc test 
increased $\mathrm{mAb}$ productivities compared to linear PEI (155-230\%) [56]. Therefore, in this study, PEImax was used to transiently transfect $\mathrm{CHO}$ cells with Bcl-xL-bearing plasmid. It is known that DNA amount and the DNA:PEI ratio are among most important parameters for an efficient protein expression in PEI-mediated transfection [59]. Abbott et al. investigated transfection efficiencies after transfection with DNA concentrations ranging between 0.5 and $1.5 \mu \mathrm{g} / \mathrm{mL}$ and DNA:PEI ratios ranging between 1:11 and 1:3 and showed that expression levels of cells after transfection with PEImax were increased by lowered DNA:PEI ratio up to 1:9 by using Box-Behnken experimental design [60]. In the first part of this study, to determine optimum transfection conditions, DNA concentrations ranging between 0.5 and $2 \mu \mathrm{g} / \mathrm{mL}$ and DNA:PEI ratios ranging between 1:1 and 1:8 were used to transiently transfect $\mathrm{CHO}$ cells. The results indicated that transfection efficiency of cells transfected with $1 \mu \mathrm{g} / \mathrm{mL}$ DNA was significantly higher than cells transfected with $0.5 \mu \mathrm{g} / \mathrm{mL}$ DNA when DNA:PEI ratios of 1:2, 1:4, 1:6, 1:7, and 1:8 were used. Therefore, it is thought that at least $1 \mu \mathrm{g} / \mathrm{mL}$ DNA concentration is essential for this transfection procedure and use of $2 \mu \mathrm{g} / \mathrm{mL}$ DNA concentration resulting in increased transfection for only one experimental group (DNA:PEI ratio of 1:6). Although in this study $2 \mu \mathrm{g} / \mathrm{mL}$ DNA was used based on this increase $(57.7 \%)$ observed in the experimental group that DNA:PEI ratio of 1:6 was used, $1 \mu \mathrm{g} / \mathrm{mL}$ DNA may be proper for large-scale production as well. Moreover, the results have indicated that lower DNA:PEI ratios (1:6, 1:7, and 1:8) provided higher transfection efficiency and higher cell viability after transfection. However, the increase in transfection efficiency was not continued when DNA:PEI ratio was decreased below 1:6 (1:7 and 1:8). This result has shown that PEI:DNA ratio can be decreased to $6: 1$ at most to maintain efficient transfection in this procedure. Besides PEI, LPF that is a cation-lipid formulation transfection reagent was used to transiently transfect $\mathrm{CHO}$ cells with Bcl-xL-bearing plasmid. However, it is known that LPF is not a highly preferable transfection reagent by virtue of its high cost and lower scalability for large-scale production. Furthermore, transfection efficiencies obtained from cells transfected with DNA:LPF complexes resulted in considerably different transfection efficiencies ranging between 3.8 and $15 \%$ in this study.

Suppression of apoptosis has been considered a remarkable strategy to enhance product yield via increasing survival of cells. The anti-apoptotic strategies have been accelerated by gaining knowledge in the matter of apoptotic cascade and important components in this process $[23,32,33]$. The bcl-2 anti-apoptotic gene is the mostly investigated and used to overexpress in commercial cell lines and enhance cell viability [31, 32, 61, 62]. Besides bcl-2, Bcl-xL, which is bcl-2 family member, has been studied as well for the same purpose [28-30, 63]. Various studies were indicated that the overexpression of Bcl-xL gave better results rather than Bcl-2 to enhance production in $\mathrm{CHO}$ cells [32, 33, 63]. In addition, Templeton et al. reported that the increase in the total biomass yield through anti-apoptotic engineering enhances the peak viable cell density and thus enhances the integrated viable cell density that results in higher recombinant protein production [64].

In this study, the effect of overexpression of Bcl-xL on viability and anti-TNF- $\alpha$ production of the $\mathrm{CHO}$ cell line that stably produces humanized anti-TNF- $\alpha$ mAb were investigated using different transfection procedures. It was observed that transfection with complex of Bcl-xLbearing plasmid:PEI reagent provided enhanced cell viabilities compared to non-transfected control group (increase by approximately 12\%) at the second day of transfection when DNA:PEI ratio of 1:6 and 1:8 were used in transfection. As for transfection with complex of Bcl-xL-bearing plasmid:LPF reagent, cell viability was increased by $9 \%$ when DNA:LPF ratio of 1:1.8 was used in transfection. Moreover, staurosporine, which is known to induce 
apoptosis in several cell lines including $\mathrm{CHO}$ cells [65], was used to evaluate the anti-apoptotic activity of Bcl-xL in anti-TNF- $\alpha$ mAb producing stable $\mathrm{CHO}$ cells. The results indicated that transfection with Bcl-xL-bearing plasmid enhanced cell viability with increases between approximately 25 and $40 \%$ after staurosporine treatment depending on changed transfection parameters. Previous studies indicated that Bcl-xL transfection provided increased cell viabilities in CHO cells with wide range of percentages [27, 33, 66] depending on culture and transfection parameters. The reason of the fact that increases in cell viabilities after Bcl-xL transfection were low in this study is transfection efficiencies not exceeding $16 \%$. Anti-TNF- $\alpha$ $\mathrm{mAb}$ producing stable $\mathrm{CHO}$ cells did not allow higher expression of the plasmid in transfection procedures discussed in this research. Zustiak et al. showed that although the growth and viability of all cultures were similar in Bcl-xL-expressing and Bcl-xL-not-expressing cell groups, the final product titers were increased significantly by transfection with Bcl-xL [35]. Similarly, in this study despite relatively low increase in cell viability arisen with Bcl-xL transfection, the production of anti-TNF- $\alpha$ was increased up to 2.07-fold with transfection by LPF reagent, up to 1.6-fold with transfection by PEI reagent, and product yield coefficients of cells were increased up to 0.98 via with Bcl-xL transfection. All taken together, it is shown that overexpression of Bcl-xL provides higher production of anti-TNF- $\alpha \mathrm{mAb}$ up to $215 \mathrm{mg} / \mathrm{mL}$ compared to $134 \mathrm{mg} / \mathrm{mL}$ producing control group and the strategy discussed in this paper have a potential for large-scale production of biosimilars through TGE.

\section{Conclusion}

The methods for delaying cell apoptosis have been largely considered as a highly promising and advantageous strategy to increase product yield and quality and reduce production costs in medical biotechnology applications. Previous studies using anti-apoptotic cell engineering via overexpression of anti-apoptotic genes have succeeded at different recombinant proteins in various hosts. In this study, it has been shown that it is possible to delay apoptosis in CHO cells and induce higher TNF- $\alpha$ antibody production by using overexpression of Bcl-xL antiapoptotic protein in trough TGE which can be a promising technology to enhance the production yield both in biosimilar production that is a growing market in biopharmaceutical production and in innovators which are entering the pipeline to be clinically evaluated.

Acknowledgements This study has been partly funded by TUBITAK through 2209-A project number 1919B011402737 under the supervision of Sultan GULCE IZ, PhD.

\section{References}

1. Reichert, J. M. (2008). Monoclonal antibodies as innovative therapeutics. Current Pharmaceutical Biotechnology, 9, 423-430.

2. Reichert, J. M., Rosensweig, C. J., Faden, L. B., \& Dewitz, M. C. (2005). Monoclonal antibody successes in the clinic. Nature Biotechnology, 23, 1073-1078.

3. Rodrigues, M. E., Costa, A. R., Henriques, M., Azeredo, J., \& Oliveira, R. (2013). Advanced and drawbacks of adaptation to serum-free culture of CHO-K1 cells for monoclonal antibody production. Applied Biochemistry and Biotechnology, 169, 1279-1291.

4. Nelson, A. L., Dhimolea, E., \& Reichert, J. M. (2010). Development trends for human monoclonal antibody therapeutics. Nature Reviews Drug Discovery, 9, 767-774. 
5. Farid, S. S. (2008). Economic drivers and trade-offs in antibody purification processes. BioPharm International, 21, 37-42.

6. Farid, S. S. (2007). Process economics of industrial monoclonal antibody manufacture. Journal of Chromatography B, 848, 8-18.

7. Bradley, J. (2008). TNF-mediated inflammatory disease. The Journal of Pathology, 214, 149-160.

8. Parameswaran, N., \& Patial, S. (2010). Tumor necrosis factor- $\alpha$ signaling in macrophages. Critical Reviews $^{\mathrm{TM}}$ Eukaryotic Gene Expression, 20(2), 87-103.

9. Clark, I. A. (2007). How TNF was recognized as a key mechanism of disease. Cytokine \& Growth Factor Reviews, 18, 335-343.

10. Balabashin, D., Kovalenko, E., Toporova, V., Aliev, T., Panina, A., Svirshchevskaya, E., Dolgikh, D., \& Kirpichnikov, M. (2015). Production of anti TNF- $\alpha$ antibodies in eukaryotic cells using different combinations of vectors carrying heavy and light chains. Cytotechnology, 67, 761-772.

11. Horiuchi, T., Mitoma, H., Harashima, S.-I., Tsukamoto, H., \& Shimoda, T. (2010). Transmembrane TNF- $\alpha$ : structure, function and interaction with anti-TNF agents. Rheumatology, 49, 1215-1228.

12. Jayapal, K. P., Wlaschin, K. F., Hu, W. S., \& Yap, M. G. S. (2007). Recombinant protein therapeutics from CHO cells - 20 years and counting. Chemical Engineering Progress, 103(10), 40- 47.

13. Lis, K., Kuzawińska, O., \& Bałkowiec-Iskra, E. (2014). Tumor necrosis factor inhibitors-state of knowledge. Archives of Medical Science, 10, 1175-1185.

14. (2012). Biologic drugs set to top 2012 sales. Nat Med, 18, 636-636.

15. Willrich, M. A., Murray, D. L., \& Snyder, M. R. (2015). Tumor necrosis factor inhibitors: clinical utility in autoimmune diseases. Translational Research, 165, 270-282.

16. Ghaderi, D., Zhang, M., Hurtado-Ziola, N., \& Varki, A. (2012). Production platforms for biotherapeutic glycoproteins. Occurrence, impact, and challenges of non-human sialylation. Biotechnology and Genetic Engineering Reviews, 28, 147-176.

17. Swiech, K., Picanço-Castro, V., \& Covas, D. T. (2012). Human cells: new platform for recombinant therapeutic protein production. Protein Expression and Purification, 84, 147-153.

18. Estes, S., \& Melville, M. (2013). Advances in biochemical engineering biotechnology, vol 139: mammalian cell cultures for biologics manufacturing. In W. Zhou \& A. Kantardjieff (Eds.), Mammalian cell line developments in speed and efficiency (pp. 11-33). Berlin Heidelberg: Springer-Verlag.

19. Kim, J. Y., Kim, Y.-G., \& Lee, G. M. (2012). CHO cells in biotechnology for production of recombinant proteins: current state and further potential. Applied Microbiology and Biotechnology, 93, 917-930.

20. Barnes, L. M., Bentley, C. M., \& Dickson, A. J. (2001). Characterization of the stability of recombinant protein production in the GS-NS0 expression system. Biotechnology and Bioengineering, 73, 261-270.

21. Page, M. J., \& Sydenham, M. A. (1991). High level expression of the humanized monoclonal antibody Campath-1H in Chinese hamster ovary cells. Nature Biotechnology, 9, 64-68.

22. Al-Rubeai, M. (1998). Advances in biochemical engineering biotechnology, vol 59: bioprocess and algae reactor technology, apoptosis. In T. Scheper (Ed.), Apoptosis and cell culture technology (pp. 225-249). Berlin Heidelberg: Springer-Verlag.

23. Arden, N., \& Betenbaugh, M. J. (2004). Life and death in mammalian cell culture: strategies for apoptosis inhibition. Trends in Biotechnology, 22, 174-180.

24. Al-Rubeai, M., \& Singh, R. P. (1998). Apoptosis in cell culture. Current Opinion in Biotechnology, 9, $152-156$.

25. Goswami, J., Sinskey, A., Steller, H., Stephanopoulos, G., \& Wang, D. (1999). Apoptosis in batch cultures of Chinese hamster ovary cells. Biotechnology and Bioengineering, 62, 632-640.

26. Morrow, K. J. (2007). Advances in antibody manufacturing using mammalian cells. Biotechnology Annual Review, 13, 95-113.

27. Chiang, G. G., \& Sisk, W. P. (2005). Bcl-xL mediates increased production of humanized monoclonal antibodies in Chinese hamster ovary cells. Biotechnology and Bioengineering, 91, 779-792.

28. Charbonneau, J., \& Gauthier, E. (2001). Protection of hybridoma cells against apoptosis by a loop domaindeficient Bcl-xL protein. Cytotechnology, 37, 41-47.

29. Jung, D., Côté, S., Drouin, M., Simard, C., \& Lemieux, R. (2002). Inducible expression of Bcl-XL restricts apoptosis resistance to the antibody secretion phase in hybridoma cultures. Biotechnology and Bioengineering, 79, 180-187.

30. Figueroa Jr., B., Sauerwald, T., Oyler, G., Hardwick, J. M., \& Betenbaugh, M. J. (2003). A comparison of the properties of a Bcl-x L variant to the wild-type anti-apoptosis inhibitor in mammalian cell cultures. Metabolic Engineering, 5, 230-245.

31. Tey, B., Singh, R., Piredda, L., Piacentini, M., \& Al-Rubeai, M. (2000). Bcl-2 mediated suppression of apoptosis in myeloma NS0 cultures. Journal of Biotechnology, 79, 147-159.

32. Fussenegger, M., Fassnacht, D., Schwartz, R., Zanghi, J. A., Graf, M., Bailey, J. E., \& Pörtner, R. (2000). Regulated overexpression of the survival factor bcl-2 in CHO cells increases viable cell density in batch culture and decreases DNA release in extended fixed-bed cultivation. Cytotechnology, 32, 45-61. 
33. Mastrangelo, A. J., Hardwick, J. M., Zou, S., \& Betenbaugh, M. J. (2000). Part II. Overexpression of bcl-2 family members enhances survival of mammalian cells in response to various culture insults. Biotechnology and Bioengineering, 67, 555-564.

34. Dorai, H., Kyung, Y. S., Ellis, D., Kinney, C., Lin, C., Jan, D., Moore, G., \& Betenbaugh, M. J. (2009). Expression of anti-apoptosis genes alters lactate metabolism of Chinese hamster ovary cells in culture. Biotechnology and Bioengineering, 103, 592-608.

35. Zustiak, M. P., Jose, L., Xie, Y., Zhu, J., \& Betenbaugh, M. J. (2014). Enhanced transient recombinant protein production in $\mathrm{CHO}$ cells through the co-transfection of the product gene with Bcl-xL. Biotechnology Journal, 9, 1164-1174.

36. Hauser, H. and Wagner, R. (2014). Animal cell biotechnology: In Biologics Production, $1^{\text {st }}$ ed., Walter de Gruyter GmbH \& Co KG.

37. Bos, A. B., Duque, J. N., Bhakta, S., Farahi, F., Chirdon, L. A., Junutula, J. R., Harms, P. D., \& Wong, A. W. (2014). Development of a semi-automated high throughput transient transfection system. Journal of Biotechnology, 180, 10-16.

38. Codamo, J., Munro, T. P., Hughes, B. S., Song, M., \& Gray, P. P. (2011). Enhanced CHO cell-based transient gene expression with the epi-CHO expression system. Molecular Biotechnology, 48, 109-115.

39. Hacker, D. L., Kiseljak, D., Rajendra, Y., Thurnheer, S., Baldi, L., \& Wurm, F. M. (2013). Polyethyleneimine-based transient gene expression processes for suspension-adapted HEK-293E and CHO-DG44 cells. Protein Expression and Purification, 92, 67-76.

40. Lee, S., \& Lee, G. M. (2013). Bcl-2 overexpression in CHO cells improves polyethylenimine-mediated gene transfection. Process Biochemistry, 48, 1436-1440.

41. Sou, S. N., Polizzi, K. M., \& Kontoravdi, C. (2013). Evaluation of transfection methods for transient gene expression in Chinese hamster ovary cells. Advances in Bioscience and Biotechnology, 4, 1013-1019.

42. Ehrhardt, C., Schmolke, M., Matzke, A., Knoblauch, A., Will, C., Wixler, V., \& Ludwig, S. (2006). Polyethylenimine, a cost-effective transfection reagent. Signal Transduction, 6, 179-184.

43. Longo, P. A., Kavran, J. M., Kim, M.-S., \& Leahy, D. J. (2013). Transient mammalian cell transfection with polyethylenimine (PEI). Methods in Enzymology, 529, 227.

44. Zaric, V., Weltin, D., Erbacher, P., Remy, J. S., Behr, J. P., \& Stephan, D. (2004). Effective polyethylenimine-mediated gene transfer into human endothelial cells. The Journal of Gene Medicine, 6 , 176-184.

45. Obata, Y., Ciofani, G., Raffa, V., Cuschieri, A., Menciassi, A., Dario, P., \& Takeoka, S. (2010). Evaluation of cationic liposomes composed of an amino acid-based lipid for neuronal transfection. Nanomedicine: Nanotechnology, Biology and Medicine, 6, 70-77.

46. Gulce Iz, S., Calimlioglu, B., \& Deliloglu, S. I. D. (2012). Using Bcl-xL anti-apoptotic protein for altering target cell apoptosis. Electronic Journal of Biotechnology, 15(5), 2-2.

47. Bertrand, R., Solary, E., O’Connor, P., Kohn, K. W., \& Pommier, Y. (1994). Induction of a common pathway of apoptosis by staurosporine. Experimental Cell Research, 211, 314-321.

48. Nalbantsoy, A., Karaboz, I., Ivanova, R., \& Deliloglu Gurhan, I. (2010). Isolation and purification of O and $\mathrm{H}$ antigens from Salmonella Enteritidis as diagnostic tools. Annals of Microbiology, 60, 565-571.

49. Ayyildiz Tamis, D., Deliloglu Gurhan S.I. (2016). Optimization of humanized monoclonal antibody against human tumor necrosis factor- $\alpha$ production. PhD Thesis, Ege University, Institute of Science, Thesis reference number: 10117485.

50. Toledo, J. R., Prieto, Y., Oramas, N., \& Sánchez, O. (2009). Polyethylenimine-based transfection method as a simple and effective way to produce recombinant lentiviral vectors. Applied Biochemistry and Biotechnology, 157, 538-544.

51. Haldankar, R., Li, D., Saremi, Z., Baikalov, C., \& Deshpande, R. (2006). Serum-free suspensin large-scale transient transfection of CHO cells in WAVE bioreactors. Molecular Biotechnology, 34, 191-199.

52. Rosser, M. P., Xia, W., Hartsell, S., McCAMAN, M., Zhu, Y., Wang, S., Harvey, S., Bringmann, P., \& Cobb, R. R. (2005). Transient transfection of CHO-K1-S using serum-free medium in suspension: a rapid mammalian protein expression system. Protein Expression and Purification, 40, 237-243.

53. Ye, J., Kober, V., Tellers, M., Naji, Z., Salmon, P., \& Markusen, J. F. (2009). High-level protein expression in scalable CHO transient transfection. Biotechnology and Bioengineering, 103, 542-551.

54. Galbraith, D. J., Tait, A. S., Racher, A. J., Birch, J. R., \& James, D. C. (2006). Control of culture environment for improved Polyethylenimine-mediated transient production of recombinant monoclonal antibodies by CHO cells. Biotechnology Progress, 22, 753-762.

55. Thuret, G., Chiquet, C., Herrag, S., Dumollard, J., Boudard, D., Bednarz, J., Campos, L., \& Gain, P. (2003). Mechanisms of staurosporine induced apoptosis in a human corneal endothelial cell line. British Journal of Ophthalmology, 87, 346-352.

56. Delafosse, L., Xu, P., \& Durocher, Y. (2016). Comparative study of polyethylenimines for transient gene expression in mammalian HEK293 and CHO cells. Journal of Biotechnology, 227, 103-111. 
57. Wang, W., Li, W., Ma, N., \& Steinhoff, G. (2013). Non-viral gene delivery methods. Current Pharmaceutical Biotechnology, 14, 46-60.

58. Yin, H., Kanasty, R. L., Eltoukhy, A. A., Vegas, A. J., Dorkin, J. R., \& Anderson, D. G. (2014). Non-viral vectors for gene-based therapy. Nature Reviews Genetics, 15, 541-555.

59. Derouazi, M., Girard, P., Van Tilborgh, F., Iglesias, K., Muller, N., Bertschinger, M., \& Wurm, F. M. (2004). Serum-free large-scale transient transfection of CHO cells. Biotechnology and Bioengineering, $87,537-545$.

60. Abbott, W. M., Middleton, B., Kartberg, F., Claesson, J., Roth, R., \& Fisher, D. (2015). Optimisation of a simple method to transiently transfect a $\mathrm{CHO}$ cell line in high-throughput and at large scale. Protein Expression and Purification, 116, 113-119.

61. Singh, R. P., Emery, A. N., \& Al-Rubeai, M. (1996). Enhancement of survivability of mammalian cells by overexpression of the apoptosis-suppressor gene bcl-2. Biotechnology and Bioengineering, 52, 166-175.

62. Fassnacht, D., Rössing, S., Singh, R., Al-Rubeai, M., \& Pörtner, R. (1999). Influence of bcl-2 on antibody productivity in high cell density perfusion cultures of hybridoma. Cytotechnology, 30, 95-106.

63. Meents, H., Enenkel, B., Eppenberger, H. M., Werner, R. G., \& Fussenegger, M. (2002). Impact of coexpression and coamplification of sICAM and antiapoptosis determinants bcl-2/bcl-xL on productivity, cell survival, and mitochondria number in CHO-DG44 grown in suspension and serum-free media. Biotechnology and Bioengineering, 80, 706-716.

64. Templeton, N., Lewis, A., Dorai, H., Qian, E. A., Campbell, M. P., Smith, K. D., Lang, S. E., Betenbaugh, M. J., \& Young, J. D. (2014). The impact of anti-apoptotic gene Bcl-2 $\Delta$ expression on CHO central metabolism. Metabolic Engineering, 25, 92-102.

65. Figueroa, B., Chen, S., Oyler, G. A., Hardwick, J. M., \& Betenbaugh, M. J. (2004). Aven and Bcl-xL enhance protection against apoptosis for mammalian cells exposed to various culture conditions. Biotechnology and Bioengineering, 85, 589-600.

66. Majors, B. S., Betenbaugh, M. J., Pederson, N. E., \& Chiang, G. G. (2008). Enhancement of transient gene expression and culture viability using Chinese hamster ovary cells overexpressing Bcl-xL. Biotechnology and Bioengineering, 101, 567-578. 